\author{
Serghiy Shapovalov and Yana Kiseliova
}

\title{
ASSOCIATION OF THYMOLSULFONEPHTHALEIN AND CRESOLSULFONEPHTHALEIN ANIONS WITH CATIONIC CYANINES IN AQUEOUS SOLUTION
}

\author{
V. N. Karazin Kharkiv National University, 4 Svobody sq., 61077 Kharkiv, Ukraine \\ serghey.a.shapovalov@univer.kharkov.ua
}

Received: April 22, 2010 / Revised: August 18, 2010 / Accepted: September 30, 2010

(c) Shapovalov S., Kiseliova Y., 2010

\begin{abstract}
The formation of associates between one- or twocharged anions of sulfonephthalein dyes - thymolsulfonephthalein, cresolsulfonephthalein - and cyanine cations (pinacyanol, quinaldine red) has been considered in aqueous solution. Equilibrium association constants have been determined using spectrophotometric data. By semiempirical methods the enthalpy of formation and the eventual structure of ions and associates have been established.
\end{abstract}

Keywords: association, aqueous solution, thymolsulfonephthalein, cresolsulfonephthalein, enthalpy of formation, dyes, absorption spectra.

\section{Introduction}

Phenol red or phenolsulfonephthalein (PS), and other sulfonephthaleins are traditionally applied as acid-base or metalchromic indicators in the quantitative analysis $[1,2]$. Recently, attention has been drawn to the use of alkyl PS derivatives: thymolsulfonephthalein (TS) and $o$-cresolsulfonephthalein (CS). These sulfonephthaleins manifest themselves as reagents which are highly sensitive, e.g. to the electromagnetic radiation [3] (including UVradiation [4]), as well as to the content of a number of simple inorganic ions $\left(\mathrm{Pb}^{2+}, \mathrm{Cd}^{2+}[5], \mathrm{H}^{+}[6], \mathrm{SO}_{4}^{2-}, \mathrm{PO}_{4}^{3-}\right.$ [7]), complex multi-functional organic molecules (proteins [8] and antibiotics [9]) in the films [4], in polymer matrices [6] and in solutions $[3,5,7,9,10]$. It is important that CS and TS form ion pairs in solutions. For example, the indication of sulfate-ion is based on the formation of ion pairs with squaramide in an acidic medium [10], and spectrophotometric determination of erythromycin is possible due to its association with TS [9]. Analysis of numerous publications demonstrates the need for a more detailed study of the cation-anion interactions leading to the formation of associates with anions $\left(\mathrm{HAn}^{-}, \mathrm{An}^{2-}\right)$ of CS or TS dyes.

Some facts of PS, CS and TS interactions with single-charged cationic cyanines $\left(\mathrm{Ct}^{+}\right)$were considered earlier [11-14]. However, the most probable structure of the associates as well as energetics (in particular, the enthalpy of formation, $\Delta_{\mathrm{f}} H^{\circ}$ ) were not discussed. In this report, on the basis of the results of spectrophotometric measurements and quantum chemical simulations, we have analyzed the cation-anion interaction leading to the formation of stoichiometric associates between single- or two-charged anions of CS, TS, and single-charged cations of pinacyanol $\left(\mathrm{PNC}^{+}\right)$or quinaldine red $\left(\mathrm{QR}^{+}\right)$. Associates of the PS anions are also examined to compare the properties of sulfonephthalein associates. The energetics and the most probable structures of the associates " $\mathrm{Ct}^{+}+$ $\mathrm{HAn}^{-}$", " $\mathrm{Ct}^{+}+\mathrm{An}^{2-"}$ are also discussed. Note that the $\mathrm{PNC}^{+}$ and $\mathrm{QR}^{+}$cations have proven themselves as "standard" counterions in studying of the dyes association [11, 12, 14] due to its spectral and protolytic properties.

\section{Experimental}

\subsection{Materials and Equipment}

Disodium salts of sulfonephthaleins and chlorides of cyanine dyes («Sigma») have been used. We were convinced spectrophotometrically in good cleaness of each dye taking into consideration the well-known values of molar absorption coefficient $\left(\varepsilon_{\max }, 1 /(\mathrm{mol} \cdot \mathrm{cm})\right)$ at the maximum absorption band $\left(\lambda_{\max }\right)$ of the most intensely protolytic forms. The acidity of solutions is created by phosphate, borate or acetate buffer solutions, and the chloride acid or sodium hydroxide in some cases. Supplementary experiments have revealed that additions of buffer solutions did not have a noticeable influence on the association processes. The $\mathrm{pH}$ values were monitored by a glass electrode. Ionic strength $(I)$ of photometrical solutions did not exceed $0.004 \mathrm{~mol} / \mathrm{l}$. The values of the optical density $(A)$ underlying the calculations of the equilibrium association constant $\left(K_{\mathrm{as}}\right)$ were in agreement with the basic law of light absorption. The absorption 
spectra were measured with a spectrophotometer Hitachi U3210 or "SF-46" at room temperature.

\subsection{Procedure}

Technique of preparation of dyes mixtures and the calculations of the spectral and equilibrium characteristics of the associates are given in prior publications [11-13]. General principles of quantum-chemical simulations of dyes structures and ion associates have been described previously [15]. Studying the interaction $\mathrm{HAn}^{-}\left(\right.$or $\left.\mathrm{An}^{2-}\right)$ with $\mathrm{Ct}^{+}$the acidity of the solution that would ensure the coexistence of the ionic forms was observed (otherwise, the interpretation of spectral changes is complicated due to possible interactions with other particles). By creating the optimum acidity the numerical values of $\mathrm{p} K_{\mathrm{a} 1}$ and $\mathrm{p} K_{\mathrm{a} 2}$ have been taken into account (see Table 1; characteristics of dyes are given for $I \rightarrow 0$ according to [16-19]; $\mathrm{p} K_{\mathrm{a}}$ error values are equal to $\pm(0.03-0.08)$; values of $\mathrm{p} K_{\mathrm{a} 1}$ for $\mathrm{QR}$ and PNC are given for the dissociation process of the $\mathrm{HCt}^{2+}$ cation). For example, the data in Table 1 indicate that the interaction of a single charged anion of $\mathrm{CS}^{-}$with $\mathrm{PNC}^{+}$should be investigated at $\mathrm{pH} 5.0-6.5$, and the same is at 5.5-7.2 for $\mathrm{TS}^{-}$anion.

Table 1

Spectral and protolytic properties of dyes

\begin{tabular}{|c|c|c|}
\hline Dye & $\begin{array}{c}\mathrm{p} K_{\mathrm{a} 1} \\
\left(\lambda_{\max }, \mathrm{nm} \mathrm{HAn}^{-} \text {or } \mathrm{Ct}^{+}\right)\end{array}$ & $\begin{array}{c}\mathrm{p} K_{\mathrm{a} 2} \\
\left(\lambda_{\max }, \mathrm{nm} \mathrm{An}^{2-}\right)\end{array}$ \\
\hline (O) & & \\
\hline$o$-cresolsulfonephthalein (CS), 5, $5^{\prime}-\mathbf{C H}_{3}$ & $\begin{array}{c}1.05 \\
(433)\end{array}$ & $\begin{array}{l}8.46 \\
(572)\end{array}$ \\
\hline thymolsulfonephthalein (TS), 3,3' - $\mathbf{C H}\left(\mathbf{C H}_{3}\right)_{2} ; 6,6^{\prime}-\mathbf{C H}_{3}$ & $\begin{array}{c}1.50 \\
(438)\end{array}$ & $\begin{array}{l}9.20 \\
(537)\end{array}$ \\
\hline phenolsulfonephthalein (PS), 3,3',5,5',6,6' - H & $\begin{array}{l}1.03 \\
(430)\end{array}$ & $\begin{array}{c}8.00 \\
(558)\end{array}$ \\
\hline \multicolumn{3}{|l|}{ Cyanines: } \\
\hline quinaldine red $\left(\mathrm{QR}^{+}\right)$ & $\begin{array}{l}2.63 \\
(528)\end{array}$ & \\
\hline pinacyanol $\left(\mathrm{PNC}^{+}\right)$ & $\begin{array}{c}3.5 \\
(600, \alpha \text {-band } \\
550, \beta \text { - band })\end{array}$ & \\
\hline
\end{tabular}

\section{Results and Discussion}

\subsection{Equilibria of Dyes in Aqueous Solutions}

The molecules of sulfonephthalein dyes dissociate as polybasic acids: $\mathrm{H}_{3} \mathrm{An}^{+} \rightleftarrows \mathrm{H}_{2} \mathrm{An}^{0} \rightleftarrows \mathrm{HAn}^{-} \rightleftarrows \mathrm{An}^{2-}$. Cationic and neutral protolytic forms are observed only in strongly acidic medium. Anions, especially $\mathrm{An}^{2-}$, have the most intense coloring; the absorption band $\mathrm{HAn}^{-}$and $\mathrm{An}^{2-}$ are well separated spectrally ( see $\lambda_{\text {max }}$ data in Table 1 ). These properties are favorable for the experimental study of ionic association of dyes even at very low (at $1 \cdot 10^{-6} \mathrm{~mol} / \mathrm{l}$ ) concentrations of species. Significant differences in values of $\mathrm{p} K_{\mathrm{a} 1}$ and $\mathrm{p} K_{\mathrm{a} 2}$ allow creating the acidity of the solution, in which there is only one- (or two-charged) anion.

Aqueous solutions of cationic cyanines noticeably lose color in highly acidic or alkaline solutions due to protonization (formation of $\mathrm{HCt}^{2+}$ ) or hydrolysis $(\mathrm{CtOH}$ appearance) processes, respectively. 
The interpretation of spectral changes based on the equilibrium approach (using the law of mass action) includes keeping the basic law of light absorption of the protolytic forms of interacting dyes. We found that the equations of the law $A=B+\mathrm{k} C$ (where $A$ is the optical density at $\lambda_{\text {max }}$ for protolytic forms $\mathrm{HAn}, \mathrm{An}^{2}$ or $\mathrm{Ct}^{+}, C$ is a molar concentration of the dye) have a linear character under $5 \cdot 10^{-6}-1 \cdot 10^{-4} \mathrm{~mol} / \mathrm{l}$ of CS, $5 \cdot 10^{-6}-2.5 \cdot 10^{-4} \mathrm{~mol} / \mathrm{l}$ of TS, $2 \cdot 10^{-6}-8 \cdot 10^{-5} \mathrm{~mol} / \mathrm{l}$ of PS, and $2 \cdot 10^{-6}$ $8.5 \cdot 10^{-5} \mathrm{~mol} / \mathrm{l}$ of QR. The parameter $B$ is the statistical zero, the values of the angular coefficient $\mathrm{k}$ are practically equal to $\varepsilon_{\max }$ of corresponding protolytic forms, and the correlation coefficients are $0.97-0.99$. These facts suggest that sulfonephthaleins and QR do not form dimers actually in the investigated concentration ranges. Unlike other dyes, the basic law of the light absorption for PNC is observed only at small (less than $3 \cdot 10^{-6} \mathrm{~mol} / \mathrm{l}$ ) concentrations, since this cyanine is notably prone to self-association [19]. Dimerization of PNC is characterized spectrally by a sharp absorption weakening of $\alpha$-bands and by increasing the intensity of the $\beta$-band (Table 1 ).

\subsection{Association $\mathrm{Ct}^{+}$with $\mathrm{HAn}^{-}$and $\mathrm{Ct}^{+}$ with $\mathrm{An}^{2-}$}

Analysis of changes in electronic absorption spectra of $\mathrm{Ct}^{+}$with $\mathrm{HAn}^{-}$and $\mathrm{Ct}^{+}$with $\mathrm{An}^{2-}$ mixtures reveals nonadditivity of spectral bands. Nonadditivity is the fact that the intensity of the mixture absorption of interacting counterions is systematically lower than the total light absorption of individual dye ions. A characteristic feature of the association is also an essential decrease of the absorption bands intensity. It is clearly observed at the addition of increasing amounts of sulfonephthalein to the constant concentration of cyanine. Moreover, such a phenomenon occurs regardless the initial concentrations of anions or cations (in the above molar ranges). Thus, the initial concentrations of PNC in Figs. 1 and 2 differ approximately in 100 times. $\alpha$-Band has the intensity greater than $\beta$-band for PNC in Fig. 1, and the situation is contrary in Fig. 2 (system $\mathrm{Ct}^{+}+\mathrm{HAn}^{-}$and $\mathrm{Ct}^{+}+\mathrm{An}^{2-}$ respectively; arrows indicate the direction of spectral shifts). Hypochromic shifts of $\mathrm{Ct}^{+}$absorption bands without the appearance of new bands allow to suggest the solvationseparated structure of associates (in accordance with the general features of the spectral shifts for systems of dye associates [20]).

By the methods of evaluation of stoichiometric composition (similar to $[12,13]$ ) it was found that CS and $\mathrm{TS}$ anions can form $\mathrm{Ct}^{+} \cdot \mathrm{HAn}^{-}$or $\left(\mathrm{Ct}^{+}\right)_{2} \cdot \mathrm{An}^{2-}$ associates under certain conditions (initial concentrations of counterions or molar concentrations ratio). A measure of the stability of these compounds is $K_{\text {as }}$. The value of concentration $K_{\text {as }}$ is numerically not different from the thermodynamic value because $I \leq 0.004$. The $K_{\text {as }}$ value is calculated on the basis of the mass action law (in accordance with [13]) for $\mathrm{Ct}^{+}+$ $\mathrm{HAn} \rightleftarrows \mathrm{Ct}^{+} \cdot \mathrm{HAn}^{-}$and $2 \mathrm{Ct}^{+}+\mathrm{An}^{2-} \rightleftarrows\left(\mathrm{Ct}^{+}\right)_{2} \cdot \mathrm{An}^{2-}$ equilibria. The values of $K_{\mathrm{as}}=\left[\mathrm{Ct}^{+} \cdot \mathrm{HAn}^{-}\right] \cdot\left[\mathrm{Ct}^{+}\right]^{-1} \cdot\left[\mathrm{HAn}^{-}\right]^{-1}$ and $K_{\text {as }}=\left[\left(\mathrm{Ct}^{+}\right)_{2} \cdot \mathrm{An}^{-}\right] \cdot\left[\mathrm{Ct}^{+}\right]^{\mathrm{as}} \cdot\left[\mathrm{An}^{-}\right]^{-1}$ are presented in Table 2 (the molar equilibrium concentrations of the species are in square brackets; they were determined by a spectrophotometric method).

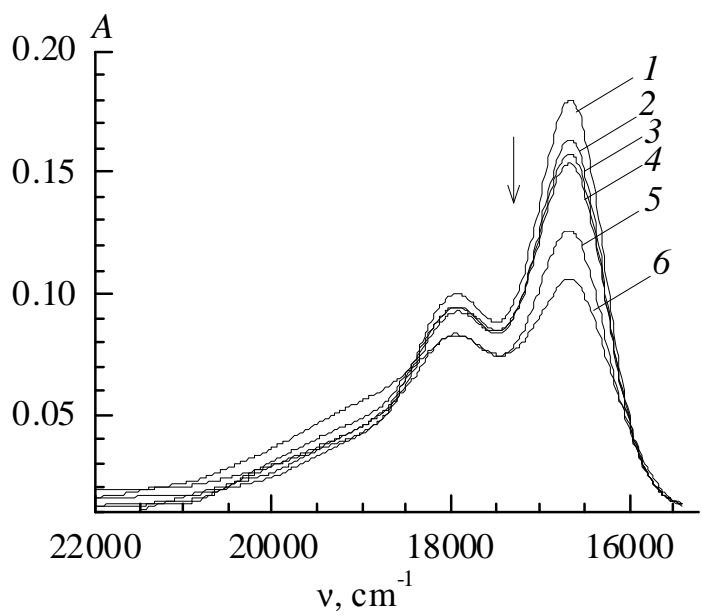

Fig. 1. Light absorbance in the "PNC + CS" system. Concentrations (mol/l) of PNC is $5.0 \cdot 10^{-7}(1-6)$; of CS: 0 (1), $5.1 \cdot 10^{-6}(2), 7.6 \cdot 10^{-6}(3), 1.5 \cdot 10^{-5}(4), 2.0 \cdot 10^{-5}(5)$ and $2.5 \cdot 10^{-5}(6)$. The thickness of absorbing layer is $5.00 \mathrm{~cm}$, pH is 5.3 . Blank solutions are: water (1) and CS at the corresponding concentrations (2-6).

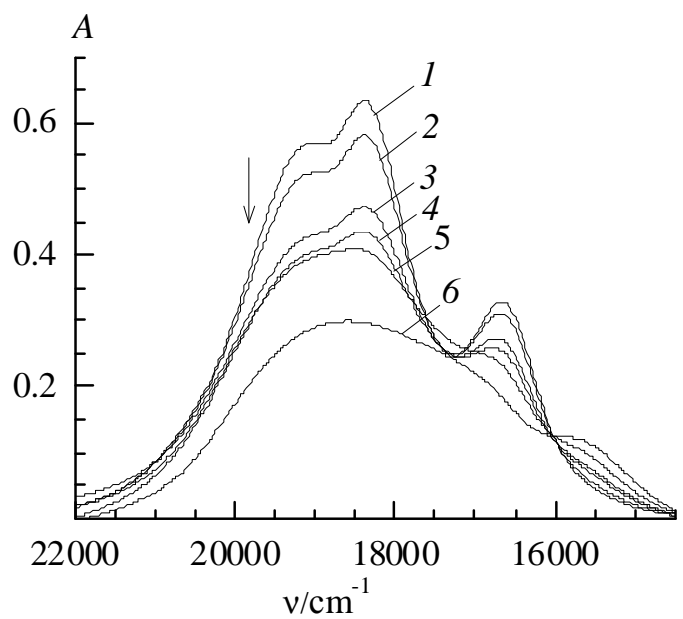

Fig. 2. Light absorbance in the "PNC + CS" system. Concentrations (mol/l) of PNC is $4.9 \cdot 10^{-5}(1-6)$; of CS: 0 (1), $5.0 \cdot 10^{-5}(2), 7.5 \cdot 10^{-5}(3), 1.0 \cdot 10^{-4}(4), 1.5 \cdot 10^{-4}(5)$ and $2.5 \cdot 10^{-4}(6)$. The thickness of absorbing layer is $0.20 \mathrm{~cm}$, $\mathrm{pH}$ is 5.3. Blank solutions are: water (1) and CS at the corresponding concentrations (2-6).

The obtained data indicate that PNC associates are more stable than QR associates. We can assume that the reason for this phenomenon is related to different 
contribution of hydrophobic and dispersion interactions in the association processes. Dispersion interactions are more typical for an advanced electronic system for PNC than for QR. By comparing the values of $K_{\text {as }}$ it is also observed that the alkyl substituents hinder the association of counterions. Moreover, the unsubstituted PS associates are more stable than the associates of substituted CS or TS. Probably this is due to the fact that the alkyl groups degrade planarity of the molecule and prevent the convergence of the ions. The dispersion interactions important for the association of dyes [13, 20] are weakened as a consequence.

Table 2

The $\lg K_{\text {as }}$ values of sulphonephtaleins associates

\begin{tabular}{|c|c|c|c|c|}
\hline \multirow{3}{*}{$\begin{array}{l}\text { Sulpho- } \\
\text { nephtalein }\end{array}$} & \multicolumn{4}{|c|}{$\lg K_{\mathrm{as}}$} \\
\hline & \multicolumn{2}{|c|}{$\mathrm{PNC}^{+}$} & \multicolumn{2}{|c|}{$\mathrm{QR}^{+}$} \\
\hline & $\mathrm{Ct}^{+} \cdot \mathrm{HAn}^{-}$ & $\left(\mathrm{Ct}^{+}\right)_{2} \cdot \mathrm{An}^{2-}$ & $\mathrm{Ct}^{+} \cdot \mathrm{HAn}^{-}$ & $\left(\mathrm{Ct}^{+}\right)_{2} \cdot \mathrm{An}^{2-}$ \\
\hline PS & $5.83 \pm 0.10$ & $11.81 \pm 0.10$ & $5.13 \pm 0.09$ & $8.64 \pm 0.09$ \\
\hline $\mathrm{CS}$ & $4.59 \pm 0.03$ & $10.96 \pm 0.10$ & $4.0 \pm 0.10$ & $6.1 \pm 0.10$ \\
\hline TS & $5.29 \pm 0.05$ & $11.0 \pm 0.1$ & $4.1 \pm 0.10$ & $5.9 \pm 0.10$ \\
\hline
\end{tabular}

The formation of associates in solutions is typical for dyes having flat shape of the molecule [19, 20]. But sulfonephthalein anions are not flat $\pi$-electronic systems. Nevertheless, as it follows from the $K_{\text {as }}$ values, the interaction between $\mathrm{Ct}^{+}$and anions is quite noticeable. On the basis of experimental data as to the associate composition it can be assumed that the planar polymethine cation is coordinated by a single charged anion (or two cations are coordinated with a twocharged anion). We examined the energy states (the $\Delta_{\mathrm{f}} H^{\circ}$ values) of each ion and associate in more detail and determined the most likely structure with the use of quantum chemical simulations.

\subsection{Energetics and Structures of Sulfonephthalein Associates}

We used semi-empirical AM1 and PM3 methods to determine $\Delta_{\mathrm{f}} H^{\circ}$ for ions and associates. The parameters of these methods have been chosen so that one should reproduce the experimental $\Delta_{\mathrm{f}} H^{\mathrm{o}}$ values of organic compounds best of all. For example, the average error of the AM1 method for calculating the enthalpy is $25 \mathrm{~kJ} / \mathrm{mol}$ $[21,22]$. It should be noted that such $a b$ initio simulation leads to $\Delta_{\mathrm{f}} H^{\mathrm{o}}$ errors that exceed $100 \mathrm{~kJ} / \mathrm{mol}$ even for small molecules. This is due to the incompleteness of the used basis and the neglect of electron correlation energy. If the number of atoms in the molecule increases, the errors of $\Delta_{\mathrm{f}} H^{\circ}$ values are even greater, and they acquire systematic character [23].

An convergence RMS gradient (Root Mean Square gradient is the rate of change (first derivative) of total energy at displacement of each atom in $\mathrm{x}, \mathrm{y}$, and $\mathrm{z}$ directions; the
RMS gradient of zero means the structure is at a local minimum in the potential energy surface). The gradient of the convergence of successive iterations decreased from 4.2 to $0.04 \mathrm{~kJ} / \mathrm{mol}$. The data in Table 3 ascertain a satisfactory convergence of results within each method of simulation. The scale of variation of $\Delta_{\mathrm{f}} \mathrm{H}^{\circ}$ values does not exceed $20 \mathrm{~kJ} / \mathrm{mol}$ (for PS, AM1 methods) and $26 \mathrm{~kJ} / \mathrm{mol}$ (for CS, PM3 method); hereinafter the most negative values of $\Delta_{\mathrm{f}} H^{\circ}$ are accepted as the final ones. A comparison between absolute $\Delta_{\mathrm{f}} H^{\circ}$ values of two semiempirical methods shows that the obtained differences are not fundamental problems in the context of the investigation. For example, the largest AM1 and PM3 difference is $44 \mathrm{~kJ} / \mathrm{mol}$ for the $\mathrm{PS}^{2-}$ ion.

\section{Table 3}

The $\Delta_{\mathrm{f}} H^{\mathrm{o}}$ values, $\mathrm{kJ} / \mathrm{mol}$, of dye ions

\begin{tabular}{|c|c|c|}
\hline \multirow{2}{*}{ Ions } & \multicolumn{2}{|c|}{ Method } \\
\cline { 2 - 3 } & $P M 3$ & $A M 1$ \\
\hline $\mathrm{CS}^{-}$ & $(-656)-(-682)$ & $(-647)-(-661)$ \\
\hline $\mathrm{CS}^{2-}$ & $(-597)-(-606)$ & $(-569)-(-570)$ \\
\hline $\mathrm{TS}^{-}$ & $(-746)-(-763)$ & $(-730)-(-746)$ \\
\hline $\mathrm{TS}^{2-}$ & $(-702)-(-712)$ & $(-667)-(-671)$ \\
\hline PS $^{-}$ & $(-575)-(-586)$ & $(-556)-(-576)$ \\
\hline PS $^{2-}$ & $(-534)-(-536)$ & $(-479)-(-492)$ \\
\hline PNC $^{+}$ & $980-968$ & $1077-1073$ \\
\hline $\mathrm{QR}^{+}$ & $918-912$ & $989-984$ \\
\hline
\end{tabular}

It is very important to determine non local but global energy minimum to obtain correct $\Delta_{\mathrm{f}} H^{\mathrm{o}}$ values of associates. We tested 6-7 different starting arrangements of counterions at the process of geometric optimization of the associate structure; previously each of the counterions has been geometrically optimized as described above. The energy state with the lowest energy corresponded to the global energy minimum. Then additional geometric structure optimization of the associate has been done by reducing RMS values, usually from 0.1 to $\left(5 \cdot 10^{-3}-\right.$ $1 \cdot 10^{-4}$ ) $\mathrm{kJ} / \mathrm{mol}$. The finishing point of optimization was determined at the absence of $\Delta_{\mathrm{f}} H^{\circ}$ changes from the RMS values. It occurred at RMS $=5.0 \cdot 10^{-2}-5.0 \cdot 10^{-3} \mathrm{~kJ} / \mathrm{mol}$ often. Initial and final locations of the ions in the $\left(\mathrm{QR}^{+}\right)_{2} \cdot \mathrm{TS}^{2-}$ associate are shown in Figs. 3 and 4 as examples (stereo; position of the anion has been arbitrarily fixed for the observer; the hydrogen atoms are omitted in Fig. 4). Distances between the carbon atom at $\mathrm{TS}^{2-}$ and each carbon atom at $\mathrm{QR}^{+}$are equal to $6.5 \AA$, the central angle with vertex on the carbon atom of $\mathrm{TS}^{2-}$ is equal to $152^{\circ}$ (see Fig. 3). Distance between the carbon atom at $\mathrm{TS}^{2-}$ and upper carbon atom of $\mathrm{QR}^{+}$is $5.5 \AA$, and the same is $4.9 \AA$ for the bottom carbon atom of $\mathrm{QR}^{+}$; the central angle with vertex on the carbon atom of $\mathrm{TS}^{2-}$ is equal to $116^{\circ}$ (see 
Fig. 4). Geometry of the structure strongly depends on the RMS values for sulfonephthalein associates. The optimization process is also characterized by decreasing the distance between the counterions and deformation of the $\pi$-electronic systems of dyes. The process has been practically completed at $\mathrm{RMS}=0.01 \mathrm{~kJ} / \mathrm{mol}$ yet.
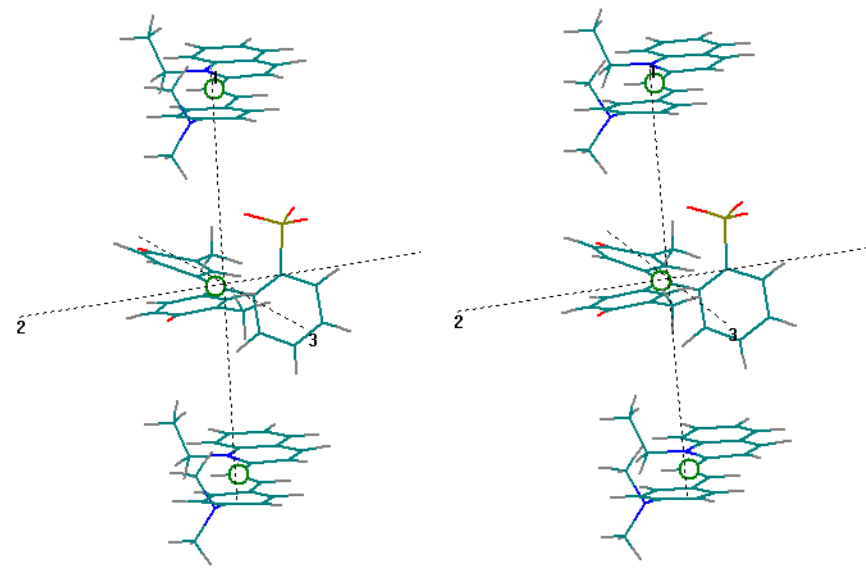

Fig. 3. Initial position of $\mathrm{TS}^{2-}$ anion (in the middle) and two $\mathrm{QR}^{+}$cations
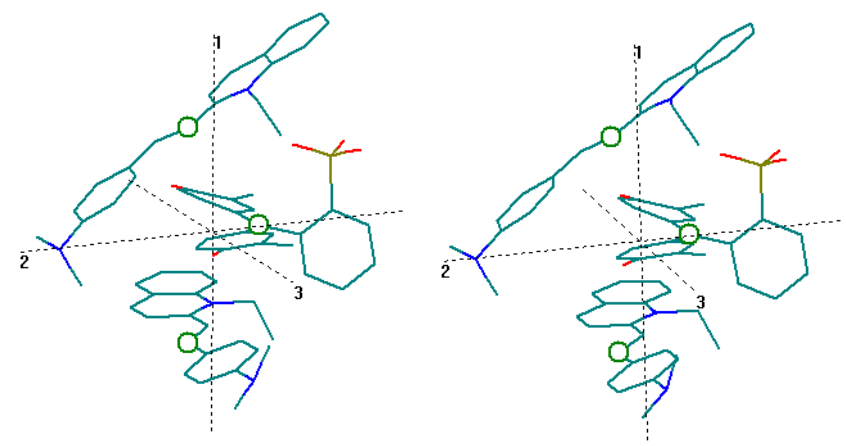

Fig. 4. Position of $\mathrm{QR}^{+}$and $\mathrm{TS}^{2-}$ ions in $\left(\mathrm{QR}^{+}\right)_{2} \cdot \mathrm{TS}^{2-}$ associate

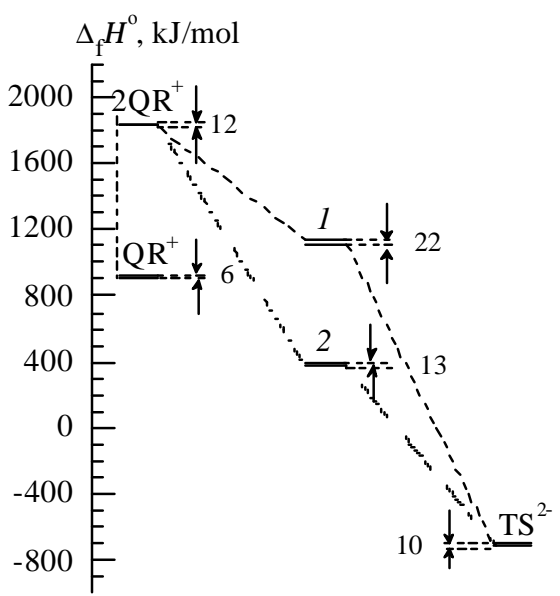

Fig. 5. The $\Delta_{\mathrm{f}} H^{\mathrm{o}}$ values of $\mathrm{QR}^{+}$and $\mathrm{TS}^{2-}$ ions: the $\Delta_{\mathrm{f}} H^{\mathrm{o}}$ value as the algebraic sum of ions (1) and the $\Delta_{\mathrm{f}} H^{\mathrm{o}}$ value of $\left(\mathrm{QR}^{+}\right)_{2} \cdot \mathrm{TS}^{2-}$ associate (2)
Energy characteristics of the ions $\mathrm{QR}^{+}, \mathrm{TS}^{2-}$ and $\left(\mathrm{QR}^{+}\right) \cdot \mathrm{TS}^{2-}$ associate are presented as an example in Fig. 5 (PM3 method; the numbers near arrows indicate the range of variation values of $\Delta_{\mathrm{f}} H^{\mathrm{o}}, \mathrm{kJ} / \mathrm{mol}$ ).

$\mathrm{QR}^{+}$and $\mathrm{TS}^{2-}$ ions are characterized by the $\Delta_{\mathrm{f}} H^{\mathrm{o}}$ values 918-912 and (-702)-(-712) $\mathrm{kJ} / \mathrm{mol}$ respectively (see Table 3). The algebraic sum of $\Delta_{f} H^{\circ}$ value of two $\mathrm{QR}^{+}$ cations and $\mathrm{TS}^{2-}$ anion is equal to $1134-1112 \mathrm{~kJ} / \mathrm{mol}$ (level 1). It exceeds the $\Delta_{\mathrm{f}} H^{\mathrm{o}}$ value of $\left(\mathrm{QR}^{+}\right)_{2} \cdot \mathrm{TS}^{2-}$ associate 388 $375 \mathrm{~kJ} / \mathrm{mol}$ (level 2), and the energy excess is $759-724 \mathrm{~kJ} /$ mol. Similarly, the $\Delta_{\mathrm{f}} H^{\mathrm{o}}$ values have been calculated for other associates. These data are presented in Table 4 . This table also contains the following values: $\Sigma$ is the algebraic sum of the $\Delta_{\mathrm{f}} H^{\mathrm{o}}$ values of ions in an associate, ( $\Sigma=i \cdot \Delta_{\mathrm{f}} H^{\mathrm{o}}(\mathrm{Ct})+\Delta_{\mathrm{f}} H^{\circ}(\mathrm{An})$, where $i$ is the number of cations in an associate); $\Sigma-\Delta_{\mathrm{f}} H^{\circ}$ values; maximum relative error of $\Delta H^{\circ}$ values. The calculation of $\Sigma$ values was carried out with the involvement of $\Delta_{\mathrm{f}} H^{\circ}$ ions (from Table 3 ).

The energetic properties of the associates (PM3 method)

\begin{tabular}{|l|c|c|c|c|}
\hline \multicolumn{1}{|c|}{ Associates } & $\begin{array}{c}\Sigma, \\
\mathrm{kJ} / \mathrm{mol}\end{array}$ & $\begin{array}{c}\Delta_{\mathrm{f}} H^{\mathrm{o}}, \\
\mathrm{kJ} / \mathrm{mol}\end{array}$ & $\begin{array}{c}\Sigma-\Delta_{\mathrm{f}} H^{\mathrm{o}}, \\
\mathrm{kJ} / \mathrm{mol}\end{array}$ & $\begin{array}{c}\text { Relative } \\
\text { error of } \\
\Delta_{\mathrm{f}} H^{\mathrm{o}}, \%\end{array}$ \\
\hline $\mathrm{PNC}^{+} \cdot \mathrm{CS}^{-}$ & 287 & 104 & 183 & 36 \\
\hline $\mathrm{QR}^{+} \cdot \mathrm{CS}^{-}$ & 230 & 62 & 168 & 23 \\
\hline$\left(\mathrm{PNC}^{+}\right)_{2} \cdot \mathrm{CS}^{2-}$ & 1331 & 630 & 701 & 18 \\
\hline$\left(\mathrm{QR}^{+}\right)_{2} \cdot \mathrm{CS}^{2-}$ & 1219 & 476 & 743 & 7 \\
\hline $\mathrm{PNC}^{+} \cdot \mathrm{TS}^{-}$ & 205 & 24 & 181 & 24 \\
\hline $\mathrm{QR}^{+} \cdot \mathrm{TS}^{-}$ & 149 & -45 & 194 & 25 \\
\hline$\left(\mathrm{PNC}^{+}\right)_{2} \cdot \mathrm{TS}^{2-}$ & 1225 & 514 & 711 & 10 \\
\hline$\left(\mathrm{QR}^{+}\right)_{2} \cdot \mathrm{TS}^{2-}$ & 1113 & 375 & 738 & 20 \\
\hline $\mathrm{PNC}^{+} \cdot \mathrm{PS}^{-}$ & 382 & 134 & 248 & 9 \\
\hline $\mathrm{QR}^{+} \cdot \mathrm{PS}^{-}$ & 326 & 122 & 204 & 8 \\
\hline$\left(\mathrm{PNC}^{+}\right)_{2} \cdot \mathrm{PS}^{2-}$ & 1400 & 688 & 712 & 7 \\
\hline$\left(\mathrm{QR}^{+}\right)_{2} \cdot \mathrm{PS}^{2-}$ & 1288 & 518 & 770 & 4 \\
\hline
\end{tabular}

Analysis of the data from Table 4 and the obtained results lead to several conclusions. It can be argued that the formation of associates is energetically favourable because an error of calculated $\Sigma-\Delta_{\mathrm{f}} H^{\circ}$ values is not above mentioned average error of the method for calculating $\Delta_{\mathrm{f}} H^{\circ}$ (the error highest value is $36 \%$ for $\mathrm{PNC}^{+} . \mathrm{CS}^{-}$associate; errors are less than $25 \%$ for the rest associates). The gain reaches about 168-204 kJ/mol (single charged associates) and 701-770 kJ/mol (two charged associates).

It should be noted that changes in values $\Delta_{\mathrm{f}} H^{\mathrm{o}}$ (vacuum) and $K_{\text {as }}$ (solution) do not necessarily correspond to each other, since the semi-empirical simulation cannot take into consideration certain interactions (e.g., hydrophobic interactions which are characteristic for bulky 
polyatomic counterions $[10,12])$. Nevertheless, the variation of $\Delta_{\mathrm{r}} H^{\circ}$ (values are in parentheses), turned out to be the same as well as to $K_{\mathrm{ac}}$. For $\mathrm{PNC}^{+}$associates:

$\mathrm{PNC}^{+} \cdot \mathrm{TS}^{-}(24)<\mathrm{PNC}^{+} \cdot \mathrm{CS}^{-}(104)<\mathrm{PNC}^{+} \cdot \mathrm{PS}^{-}(134)$, $\left(\mathrm{PNC}^{+}\right)_{2} \cdot \mathrm{TS}^{2-}(514)<\left(\mathrm{PNC}^{+}\right)_{2} \cdot \mathrm{CS}^{2-}(630)<\left(\mathrm{PNC}^{+}\right)_{2} \cdot \mathrm{PS}^{2-}$ (688),

and for $\mathrm{QR}^{+}$associates:

$\mathrm{QR}^{+} \cdot \mathrm{TS}^{-}(-45)<\mathrm{QR}^{+} \cdot \mathrm{CS}^{-}(62)<\mathrm{QR}^{+} \cdot \mathrm{PS}^{-}(122)$,

$\left(\mathrm{QR}^{+}\right)_{2} \cdot \mathrm{TS}^{2-}(375)<\left(\mathrm{QR}^{+}\right)_{2} \cdot \mathrm{CS}^{2-}(476)<\left(\mathrm{QR}^{+}\right)_{2} \cdot \mathrm{PS}^{2-}(518)$.

\section{Conclusions}

Thus, the identified differences of $K_{\text {as }}$ and $\Delta_{\mathrm{r}} H^{\circ}$ values have a regular character in the series of the same type on the associates' structure. The obtained results also indicate that the processes of dyes association are accompanied by a rather complicated combination of various interactions including dispersive and $\pi$-electronic interactions. The effective investigation of these processes will imply a comparison of the results of spectral measurements with the data of computer simulation in the future.

\section{References}

[1] Bishop E.: Analyst, 1971, 96, 537.

[2] Yamamoto K. and Adachi K.: Anal. Sci., 2003, 19, 1133.

[3] Khan H.M., Tabassum S. and Wahid M.: J. Radioanal. Nuclear Chem., 2009, 280, 635.

[4] Abdel-Fattah A., El-Sayed H. and El-Din E.: J. Photochem. Photobiol. A, 2000, 137, 37.

[5] Balderas-Hernandez P., Rojas-Hernandez A., Galvan M. et al.: Spectrochim. Acta. A, 2007, 66, 68.

[6] Moreno M., Martinez A., Millan P. and Camara C.: J. Mol. Struct., 1986. 143, 553.

[7] Pina M., Soberats B., Rotger C. et al.: New J. Chem., 2008, 32, 1919.

[8] Molnar-Perl I., Pinter-Szakacs M. and Medzihradszky D.: Food Chem., 1990, 35, 69.

[9] Dabrowska D., Regosz A., Piaekos R. et al.: Microchem. J., 1990, 41, 210.
[10] Pina M., Rotger M., Costa A. et al.: Tetrahedron Lett., 2004, 45, 3749.

[11] Shapovalov S., Svishchova Y. and Larin V.: Ukr. Khim. Zh., 2002, 68, 107.

[12] Shapovalov S. and Svishchova Y.: Zh. Priklad. Khimii, 2002, 75, 463.

[13] Shapovalov S., Koval V., Chernaya T. et al.: J. Brazil. Chem. Soc., 2005, 16, 232.

[14] Shapovalov S., Dobriyan M. and Sakhno T.: Izv. Vyzov. Khimiya i Khim. Techn., 2008, 51, 38.

[15] Shapovalov S., Samoilov Y. and Ivanov V.: Izv. Vyzov. Khimiya i Khim. Techn., 2006, 49, 39.

[16] Gupta D. and Read J.: J. Pharm. Sci., 1970, 11, 1683.

[17] Bishop E. (Ed.): Indikatory, V.1. Mir, Moskwa 1976.

[18] Herz A.: Photogr. Sci. Eng., 1974, 18, 207.

[19] Shapovalov S. and Samoilov Y.: Izv. Aklademii Nauk. Ser. Khimicheskaya, 2008, 1379.

[20] Ishchenko A. and Shapovalov S.: Zh. Priklad. Spektroskopii, 2004, 71, 557.

[21] Dewar M. and Storch D.: J. Amer. Chem. Soc., 1985, 107, 3898.

[22] Stewart J.: J. Computat. Chem., 1989, 10, 221.

[23] Astakhov S., Baranov V. and Gribov L.: Theory and Methods of Computational Vibronic Spectroscopy. Nova Science Publishers, New York 2008.

\section{АСОЦАЦІЯ АНІОНІВ ТИМОЛСУЛЬФОФТАЛЕЇНА І КРЕЗОЛСУЛЬФОФТАЛЁ̈НА 3 КАТІОННИМИ ЦІАНІНАМИ У ВОДНОМУ РОЗЧИНІ}

Анотація. Розглянуто утворення у водному розчині асоиіатів між одно- або двозарядними аніонами сульфофталеїнових барвників - тимолсульфофталеїну, крезолсульфофталеӥну - і катіонами ціанінів (пінаціанол, хінальдиновий червоний). За допомогою спектрофотометричних даних визначено рівноважні константи асоціації. Напівемпіричними методами розрахована ентальпія утворення йонів і асоичіатів, встановлено їх ймовірну будову.

Ключові слова: асоиіачія, водний розчин, тимолсульфофталеїн, крезолсульфофталеїн, ентальпія утворення, барвники, спектри поглинання. 